Research Article

\title{
Urinary Incontinence in Women Living in Nursing Homes: Prevalence and Risk Factors
}

\author{
Inkontinensia Urin pada Perempuan yang Tinggal di Panti Werdha: \\ Prevalensi dan Faktor Risiko
}

\author{
Chairul Rijal, Surahman Hakim \\ Department of Obstetrics and Gynecology \\ Faculty of Medicine University of Indonesia/ \\ Dr. Cipto Mangunkusumo Hospital \\ Jakarta
}

\begin{abstract}
Objective: To identify the prevalence of urinary incontinence, the distribution of the type of urinary incontinence and related risk factors in women older than 50 years.

Method: This is a descriptive study with cross sectional design. Two hundred and seventy eight women older than 50 years old living in nursing home were interviewed using the Questionnaire for Urinary Incontinence Diagnosis (QUID) that has been translated and validated. The prevalence will be presented in the form of percentage; while the relationship between risk factors and the incidence or urinary incontinence will be analyzed using Chi square test or Fisher's exact test, as appropriate, and multivariate analysis.
\end{abstract}

Result: Of 278 research subjects, we obtained 95 subjects (34.2\%) suffering from urinary incontinence. Moreover, the distribution of the type is 67 subjects (70.5\%) with mixed urinary incontinence, 17 $(17.9 \%)$ with stress incontinence and 11 subjects $(11.6 \%)$ with urge incontinence. Body mass index (BMI) showing overweight and obesity are not related with the prevalence of urinary incontinence ( $p>0.05$ ), which may be caused by the low number of subjects with overweight and obesity. Meanwhile, factors related to urinary incontinence are age older than 60 years $(\mathrm{OR}=7.79, \mathrm{p}=0.021)$, menopause 10 years $(\mathrm{OR}=5.08, \mathrm{p}=0.004)$ and multiparity $(\mathrm{OR}=1.82, \mathrm{p}=0.019)$. Based on multivariate analysis, the risk factor of age older than 60 years is no longer related to urinary incontinence $(p>0.05)$. Thus it can be inferred that age older than 60 years is not a singular factor causing urinary incontinence but rather a part of a multifactorial model.

Conclusion: This study shows that the prevalence of urinary incontinence in women living in nursing home is $34.2 \%$; while the distribution of the urinary incontinence is 67 subjects $(70.5 \%)$ with mixed urinary incontinence, 17 subjects with stress incontinence (17.9\%) and 11 subjects $(11.6 \%)$ with urge incontinence. Risk factors for urinary incontinence are menopause 10 years and multiparity.

[Indones J Obstet Gynecol 2014; 4: 193-198

Keywords: mixed urinary incontinence, menopause, multiparity, prevalence, stress incontinence, urge incontinence, urinary incontinence, Questionnaire for Urinary Incontinence Diagnosis (QUID)

\section{Abstrak}

Tujuan: Untuk mengetahui prevalensi inkontinensia urin, sebaran tipe inkontinensia urin dan faktor-faktor risiko yang berhubungan pada perempuan berusia di atas 50 tahun.

Metode: Penelitian ini merupakan penelitian deskriptif dengan desain potong lintang. Sebanyak 278 perempuan berusia di atas 50 tahun yang tinggal di panti werdha, telah dilakukan wawancara secara terpimpin menggunakan Questionnaire for Urinary Incontinence Diagnosis (QUID) yang telah diterjemahkan dan divalidasi. Prevalensi inkontinensia urin disajikan dalam bentuk persentase, sedangkan hubungan antara faktor risiko dengan kejadian inkontinensia urin dianalisa dengan uji Chi square atau uji Fisher sesuai sebaran data, dan juga dilakukan uji multivariat.

Hasil: Dari 278 subjek penelitian, didapatkan sebanyak 95 orang $(34,2 \%)$ menderita inkontinensia urin, dengan sebaran tipe sebagai berikut: inkontinensia urin tipe campuran 67 orang $(70,5 \%)$, inkontinensia urin tipe stres 17 orang $(17,9 \%)$ dan inkontinensia urin tipe urgency 11 orang (11,6\%). Indeks massa tubuh (IMT) berlebih dan obesitas tidak memiliki hubungan dengan kejadian inkontinensia urin $(p>0,05)$, yang dapat dijelaskan oleh sedikitnya jumlah subjek dengan IMT berlebih dan obesitas. Faktor-faktor risiko yang berhubungan dengan inkontinensia urin adalah usia di atas 60 tahun $(O R=7,79 ; p=0,021)$, menopause $>10$ tahun $(O R=5,08 ; p=0,004)$, dan multipara ( $O R=1,82 ; p=0,019)$. Saat dilakukan uji multivariat, faktor risiko usia di atas 60 tahun didapatkan menjadi tidak berhubungan dengan kejadian inkontinensia urin $(p>0,05)$. Dari situ disimpulkan bahwa faktor usia di atas 60 tahun bukan merupakan faktor tunggal terjadinya inkontinensia urin melainkan bagian dari sebuah model multifaktorial.

Kesimpulan: Penelitian ini menunjukkan bahwa prevalensi inkontinensia urin pada perempuan yang tinggal di panti werdha adalah sebesar 34,2\%. Tipe inkontinensia urin yang ditemui adalah 67 orang dengan inkontinensia urin tipe campuran (70,5\%), 17 orang dengan inkontinensia urin tipe stres $(17,9 \%)$ dan 11 orang dengan inkontinensia urin tipe urgensi $(11,6 \%)$. Faktor-faktor risiko inkontinensia urin termasuk menopause $>10$ tahun dan multipara.

[Maj Obstet Ginekol Indones 2014; 4: 193-198]

Kata kunci: inkontinensia urin, inkontinensia urin tipe campuran, inkontinensia urin tipe stres, inkontinensia urin tipe urgensi, menopause, multipara, prevalensi, Questionnaire for Urinary Incontinence Diagnosis (QUID) 


\section{INTRODUCTION}

Urinary incontinence based on International Continence Society (ICS) is defined as involuntary loss of urine that can be demonstrated objectively and of social and hygienic problems. ${ }^{1-4}$ Urinary incontinence is a medical problem that can commonly be seen in aging patients, especially in women.5,6 This problem has serious impacts on physical (sleep disturbance and sexual intercourse), psychologic (sadness, depression, shamefulness), and social (social stigma, social isolation) wellbeing. ${ }^{1,7}$

Urinary incontinence is often not reported by the patients or their family, because such problem is considered as taboo or shameful to be discussed, the lack of knowledge regarding urinary incontinence and considering such condition as normal aging process and does not require medical help. ${ }^{4}$

Urinary incontinence is commonly met in aging female patients. The high prevalence of urinary incontinence in this group is considered as part of the aging processs. Various research has shown that the etiology of urinary incontinence is multifactorial and highly related to age and menopause. As the patient age, there are physiological changes in the urinary tract, partly caused by diseases outside the urinary tract and partly caused by structural changes in the urinary tract due to aging. These changes include reduced elasticity of the bladder and decreased strength of detrusor muscle, increasing frequency of spontaneous contraction of detrusor muscle, decreasing capability in holding urine and decreased urethral closure pressure. 8,9

The prevalence of urinary incontinence vary in the range of $5-60 \% .{ }^{14}$ In 1998, Asia Pacific Continence Advisory Board (APCAB) stated that the prevalence of urinary incontinence in Asian women is about $14.6 \%$. While a study by Wiratmoko, done in Semarang, regarding urinary incontinence showed the prevalence to be about $23.6 \%{ }^{10}$ The prevalence vary between countries because of several factors such as the difference of incontinence definition used, the study population and study methods. ${ }^{11,12}$

From various literature, it is stated that the prevalence of urinary incontinence increase in accordance with age. There is also belief that complains of involuntary urinary leakage is considered shameful or taboo or considered normal in elderly patients; thus many patients with urinary inconti- nence do not seek medical attention. Therefore, we expect that the prevalence of urinary incontinence in the general population is higher than reported and were interested in conducting a study of the prevalence of urinary incontinence with the distribution of the type and related risk factors in the general population of aging women. However, because of limitation in funds, time, and convenience in sampling, we limited the sample to women living in nursing homes.

\section{METHOD}

We performed a descriptive categorical study with cross-sectional design. The study is conducted in 3 nursing homes in Jakarta, namely the TMII nursing home, Ciracas nursing home and Cengkareng nursing home. From sample size calculation for descriptive categorical research, the sample needed is 278 samples. The study subjects were recruited consecutively until the required number of subjects is met. The samples were interviewed using QUID questionnaire that has been translated and validated. Prevalence of urinary incontinence is presented in percentage, while the relationship between risk factors and the incidence of urinary incontinence is analyzed using Chi Square or Fisher's exact test, as needed. Multivariate analysis was also performed. All statistical analysis were performed using SPSS version 20.

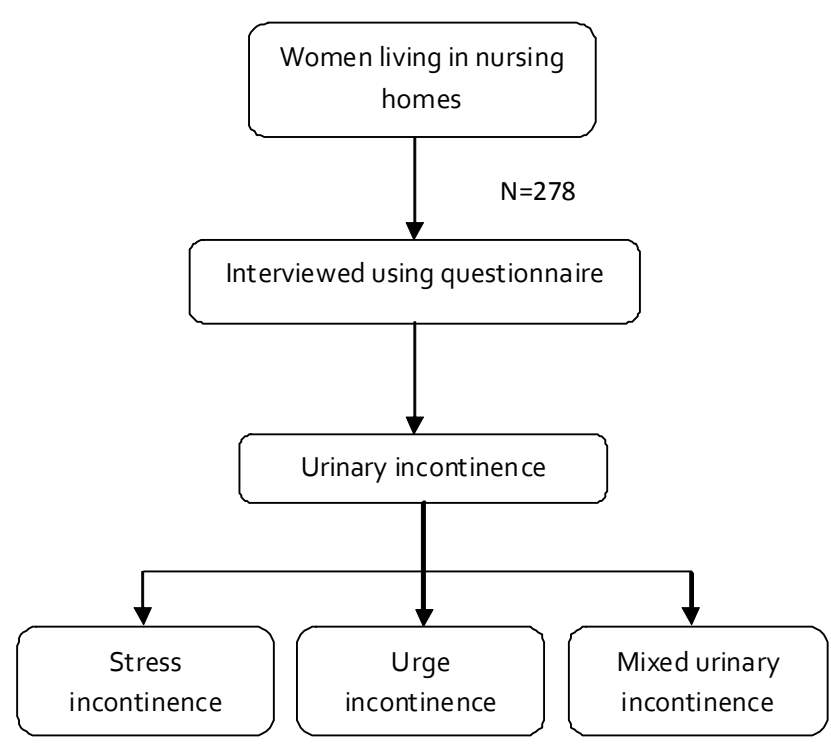

Figure 1. Scheme of the Study. 


\section{RESULT}

Table 1. Basic Characteristic of Research Subjects

\begin{tabular}{|c|c|}
\hline Characteristic & $\begin{array}{c}\text { Subject } \\
(n=278)\end{array}$ \\
\hline Age (years) & $71.5(50-95)^{*}$ \\
\hline \multicolumn{2}{|l|}{ Age group } \\
\hline Age $50-59$ year & $15(5.4)$ \\
\hline Age 60-69 year & $97(34.9)$ \\
\hline Age 70-79 year & $88(31.7)$ \\
\hline Age 80-89 year & $67(24.1)$ \\
\hline Age 90 year & $11(4.0)$ \\
\hline \multicolumn{2}{|l|}{ Body Mass Index } \\
\hline Underweight $\left(<18.5 \mathrm{~kg} / \mathrm{m}^{2}\right)$ & $24(8.6)$ \\
\hline Normal $\left(18.5-24.9 \mathrm{~kg} / \mathrm{m}^{2}\right)$ & $247(88.8)$ \\
\hline Overweight (25-29.9 kg/m²) & $6(2.2)$ \\
\hline Obese ( $30 \mathrm{~kg} / \mathrm{m}^{2}$ ) & $1(0.4)$ \\
\hline \multicolumn{2}{|l|}{ Years of menopause } \\
\hline 1-9years & $29(10.4)$ \\
\hline 10 years & $249(89.6)$ \\
\hline \multicolumn{2}{|l|}{ Method of childbirth } \\
\hline Spontaneous delivery & $278(100)$ \\
\hline Forceps extraction & - \\
\hline Vacuum extraction & - \\
\hline Cesarean section & - \\
\hline Hysterectomy & - \\
\hline \multicolumn{2}{|l|}{ Level of education } \\
\hline Did not attend formal education & $123(44.2)$ \\
\hline Elementary school & 119 (42.8) \\
\hline Junior high school & $21(7.6)$ \\
\hline Senior high school & $13(4.7)$ \\
\hline Academy or higher & $2(0.7)$ \\
\hline
\end{tabular}

Data presented as $n(\%)$ unless stated otherwise * Data presented as mean (range)
Of three nursing homes in Jakarta, we recruited 278 women who were willing to participate in the study. The mean age is 71.5 (range $=50-95$ ) years old, and most of the subjects belong to the 60-69 year old and 70-79 years old age-groups, which are $97(34.9 \%)$ and 88 (31.7\%) respectively. Around $89 \%$ of samples have normal body mass index (BMI). All of our subjects has experienced menopause and 249 has experienced menopause 10 years $(89.6 \%)$. The demographic data of our sample is shown in Table 1.

Of 278 subjects, 95 subjects (34.2\%) experience urinary incontinence (Table 2). While based on the urinary incontinence type, 67 subjects (70.5\%) suffer from mixed urinary incontinence, 17 subjects $(17.9 \%)$ suffer from stress incontinence and 11 subjects $(11.6 \%)$ suffer from urge incontinence.

We found more urinary incontinence in subjects aged over 60 years than those younger than 60 years old. This is reflected by a statistically significant relationship between the $>60$ years old age group with the risk of urinary incontinence (OR=7.79; 95\% CI=1.01-60.15; $\mathrm{p}=0.021$ ). There is also a statistically significant relationship between multiparity with the incidence of urinary incontinence compared to primiparous or nulliparous women (OR=1.82; 95\% CI=1.10-2.99; $\mathrm{p}=0.019$ ). All subjects in this study have gone through menopause. Furthermore, we found a statistically significant relationship between menopause 10 years and the incidence of urinary incontinence $(\mathrm{OR}=5.08$; 95\% $\mathrm{CI}=1.49-17.24 ; \mathrm{p}=0.004)$. While in this study, increasing BMI (classified as overweight and obese) is not related to the incidence of urinary incontinence $(p>0.05)$. The risk factors associated with urinary incontinence are presented in Table 3.

Table 2. The Prevalence of Urinary Incontinence

\begin{tabular}{lccc}
\hline \hline Urinary incontinence & $\mathbf{N}$ & $\mathbf{\%}$ & $\mathbf{9 5 \%} \mathbf{C I}$ \\
\hline Yes & 95 & 34.2 & $31.4-37$ \\
No & 183 & 65.8 & \\
\hline Amount & 278 & 100 & \\
\hline \hline
\end{tabular}


Table 3. Risk Factors Associated with Urinary Incontinence.

\begin{tabular}{|c|c|c|c|c|c|}
\hline & Risk Factors & $\begin{array}{c}\text { Urinary } \\
\text { incontinence }\end{array}$ & $\begin{array}{l}\text { No urinary } \\
\text { incontinence }\end{array}$ & OR $(95 \% \mathrm{CI})$ & $\mathbf{p}$ \\
\hline Age & $\begin{array}{c}60 \\
50-59\end{array}$ & $\begin{array}{l}94(35.7) \\
1(6.7)\end{array}$ & $\begin{array}{l}169(64.3) \\
14(93.3)\end{array}$ & $\begin{array}{c}7.79(1.01-60.15) \\
\text { Ref }\end{array}$ & 0.021 \\
\hline Parity & $\begin{array}{c}\text { Multiparity } \\
\text { Nulli- or primiparous }\end{array}$ & $\begin{array}{l}53(41.4) \\
42(28.0)\end{array}$ & $\begin{array}{l}75(58.6) \\
108(72.0)\end{array}$ & $\begin{array}{c}1.82(1.10-2.99) \\
\text { Ref }\end{array}$ & 0.019 \\
\hline Menopause & $\begin{array}{l}10 \text { years } \\
1-9 \text { years }\end{array}$ & $\begin{array}{l}92(36.9) \\
3(10.3)\end{array}$ & $\begin{array}{l}157(63.1) \\
26(89.7)\end{array}$ & $\begin{array}{c}5.08(1.49-17.24) \\
\text { Ref }\end{array}$ & 0.004 \\
\hline Body mass index (BMI) & $\begin{array}{l}\text { Overweight }+ \text { obese } \\
\text { Underweight }+ \text { normal }\end{array}$ & $\begin{array}{c}1(14.3) \\
94(34.7)\end{array}$ & $\begin{array}{c}6(85.7) \\
177(65.3)\end{array}$ & $\begin{array}{c}0.31(0.04-2.64) \\
\text { Ref }\end{array}$ & 0.428 \\
\hline
\end{tabular}

From multivariate analysis, it is obtained that age, compared to other factors (multiparity and onset of menopause), is statistically insignificant. The data is presented in our original thesis.

\section{DISCUSSION}

Urinary incontinence is a condition in which the patient present with complaints regarding involuntary urine loss. Such disorder is related to quality of live and daily activity, because patients lose their self-confidence and may feel depressed, ashamed and anxious. ${ }^{1,7}$

In this study, we recruited 278 women, meeting the required sample based on previous calculations. This study was done by interviewing women using Questionnaire for Urinary Incontinence Diagnosis (QUID) that has been translated and validated. The "r" Cronbach alpha value for questions regarding stress type urinary incontinence is 0.965 while for urge incontinence is 0.962 . Thus, we conclude that the reliability and validity of this questionnaire is good.

We observed that the mean age of our subjects is 71.5 years (range $=50-95$ years) and all subjects had experienced menopause, with the proportion of subjects already experiencing menopause for 10 years adding up to $89.6 \%$. In this study, 95 subjects (34.2\%) had urinary incontinence and 183 subjects $(65.8 \%)$ did not. This result is in accordance with studies from other countries where the prevalence of urinary incontinence in women living in nursing homes varied around 30-60\%.4,5,13,14 A study done in America on women living in nursing home showed that the prevalence of urinary incontinence is $37 \% .^{15}$ Moreover, research done by Wiratmoko showed that the prevalence of urinary incontinence in women aged $>50$ years old in Semarang was $23.6 \%{ }^{15}$ The interstudy difference in urinary incontinence prevalence is caused by the difference of urinary incontinence definition, the methods employed, the age group, country and ethnicity of the subjects in the study. 3,6

This study obtained the prevalence of urinary incontinence in women aged 50 years based on the type of the urinary incontinence is as follow: prevalence of mixed urinary incontinence was $70.5 \%$; stress incontinence was $17.9 \%$; while urge incontinence was $11.6 \%$. Such result is in accordance with the study by Wiratmoko, in which mixed urinary incontince is the type most commonly found in women aged $>50$ years. ${ }^{15}$ Similar results was also obtained by Juliana et al in Brazil, where the prevalence of mixed urinary incontinence was $36.2 \%$, urge incontinence was $26.8 \%$ and stress incontinence was $24.2 \%{ }^{16}$ Previous literature explained that women who has gone through menopause (experiencing hypoestrogen state) will experience urethral mucosa atrophy causing urethral dysfunction and weakness of bladder musculature causing bladder dysfunction, which may cause urinary incontinence, especially mixed urinary incontinence. ${ }^{8,9}$

The prevalence of urinary incontinence increases in accordance with age. From this study, the prevalence of urinary incontinence is $6.7 \%$ in the $50-59$ years age group, $28.9 \%$ in the $60-69$ years age group, $35.2 \%$ in the $70-79$ years age group and $47.8 \%$ in the $80-89$ years age group. However, the prevalence decreased to $27.3 \%$ in the 90 years age group. This is probably due to the lack of subjects aged 90 years old. From the study done by Hannested in women from all age groups, it is known that there is increasing prevalence of uri- 
nary incontinence until the age of 50 (reaching up to $50 \%$ ), then the prevalence will plateau or decrease from the age 50-70 years old, and increase again in those more than 70 years old. ${ }^{17,18}$

In terms of parity, no statistically significant relationship was found between nulliparous and parous women. However, there is a statistically significant relationship between multiparity and urinary incontinence with $\mathrm{p}=0.019$ and OR 1.82 . Based on a study done in Australia, it was found that parity is closely related to the incidence of urinary incontinence in younger women (18-23 years). For women aged 45-50 years old, only minimal relationship was found, and no relationship was found in aging population (70-75 years old). ${ }^{19,20}$

All subjects in this study has experienced menopause. There is a statistically significant relationship between women who had menopause for 10 years with the incidence of urinary incontinence $(p=0.004)$. Women who had menopause for 10 years have a five-fold increase in the risk of urinary incontinence compared to women who had menopause for $<10$ years. This result is in accordance with previous studies by Wiratmoko, in which a significant relationship between menopause for 10 years with the incidence of urinary incontinence was identified. ${ }^{15}$

In this study, we identified no statistically significant relationship between high BMI, classified as overweight and obese, with the incidence of urinary incontinence. This may be explained by the small number of subjects with overweight and obesity. However, research by Subak et al showed that the increase of BMI by 5 unit is related to a $20 \%$ $70 \%$ increased incidence of urinary incontinence. ${ }^{21}$ From another study conducted in United Kingdom on 6424 overweight and obese women, it is concluded that there is increasing risk of stress incontinence (OR=1.4 and 2.3, respectively) and overactive bladder ( $\mathrm{OR}=1.3$ and 1.2 , respectively). ${ }^{22,23}$

The relationship of age 60 years with the incidence of urinary incontinence became insignificant when multivariate analysis was performed. This may lead to the interpretation that the age variable itself is not directly related to the increase of urinary incontinence incidence. As age increases, there is increased possibility that the subject is multiparous or having menopause 10 years. Previous literature has explained that the prevalence of urinary incontinence increase as age increases and the etiology of urinary incontinence is multi- factorial. Increasing age also cause physiological changes in urinary tract, partly caused by conditions outside the urinary tract and partly caused by structural changes in the urinary tract related to aging. These changes include reduction in detrusor muscle strength, increasing frequency of spontaneous detrusor muscle contraction, decreasing capability in holding urine and decreased urethral closure pressure. ${ }^{8}$

\section{CONCLUSION}

The prevalence of urinary incontinence in women living in nursing home aged 50 years is $34.2 \%$. There are 3 major types of urinary incontinence suffered by this population: mixed urinary incontinence (67 subjects; 70.5\%), stress incontinence (17 subjects; $17.9 \%)$ and urge incontinence (11 subjects; $11.6 \%$ ). Risk factors related to the incidence of urinary incontinence are multiparity and onset of menopause 10 years.

\section{REFERENCES}

1. Ermawati. Inkontinensia Urin Tipe Stres. In: Junizaf, Santoso BI. (eds.) Buku Ajar Uroginekologi Indonesia. Jakarta: Himpunan Uroginekologi Indonesia, Bagian Obstetri dan Ginekologi FKUI; 2011; pp: 75-91.

2. Setiati S, Pramantara IDP. Inkontinensia Urin dan Kandung Kemih Hiperaktif. Buku Ajar Ilmu Penyakit Dalam. Jakarta: Interna Publishing; 2009.

3. Nygaard I, Menefee SA, Wall LL. Lower Urinary Tract Disorders. In: Berek JS. (ed.) Berek \& Novak's Gynecology. 14th ed. Philadelphia: Lippincott Williams and Wilkins; 2007; pp: 849-96.

4. Shakespeare K, Barradell V, Orme S. Management of urinary incontinence in frail elderly women. Obstet Gynecol Reprod Med 2011; 21(10): 281-7.

5. Hunskaar S, Ostbye T, Borrie MJ. The prevalence of urinary incontinence in elderly Canadians and its association with dementia, ambulatory function, and institutionalization. Norwegian J Epidemiol 1998; 8(2): 177-82.

6. Hannestad YS, Rortveit G, Sandvik H, et al. A communitybased epidemiological survey of female urinary incontinence: The Norwegian EPINCONT Study. J Clin Epidemiol 2000; 53(11): 1150-7.

7. Alling ML, Lose G, Jorgensen T. Risk factors for lower urinary tract symptoms in women 40 to 60 years of age. Obstet Gynecol 2000; 96(3): 446-51.

8. Menezes M, Pereira M, Hextall A. Predictors of female urinary incontinence at midlife and beyond. Maturitas 2010; 65: $167-71$.

9. Nitti VW. The prevalence of urinary incontinence. Rev Urol 2001; 3(suppl I): S2-S6.

10. Wiratmoko A. Inkontinensia Urin Pada Perempuan Usia Diatas Lima Puluh Tahun. Semarang: Universitas Diponegoro; 2003. 
11. Aggazzotti G. Prevalence of urinary incontinence among institutionalized patients: a cross-sectional epidemiologic study in a midsized city in northern Italy. Urol 2000; 1(56): 245-9.

12. Bhopal R. Revisiting race/ethnicity as a variable in health research. Am J Public Health 2002; 92(2): 156-7.

13. Lagaay AM, van Asperen IA, Hijmans W. The prevalence of morbidity in the oldest old, aged 85 and over: a populationbased survey in Leiden, The Netherlands. Arch Gerontol Geriatr 1992; 15(2): 115-31.

14. Coppola L, Caserta F, Grassia A, et al. Urinary incontinence in the elderly: relation to cognitive and motor function. Arch Gerontol Geriat 2002; 35: 27-34.

15. Walid MS. Prevalence of urinary incontinence in female residents of American homes and association with neuropsychiatric disorders. J Clin Med Res 2009; 1: 37-9.

16. Burti JS, Santos AMB, Pereira RMR, et al. Prevalence and clinical characteristics of urinary incontinence in elderly individuals of a low income. Arch Gerontol Geriat 2012; 54: e42-e6.

17. Cardozo L, Staskin D. Textbook of Female Urology and Urogynaecology. London: Martin Dunitz; 2002: 11-46
18. Miller YD, Brown WJ, Russell A, et al. Urinary incontinence across the lifespan. Neurourol Urodynamics 2003; 22: 5507.

19. Chiarelli P, Brown W, McElduff P. Leaking urine: prevalence and associated factors in Australian women. Neurourol Urodynamics 1999; 18: 567-77.

20. Rortveit G, Hannestad YS, Daltveit AK, et al. Age and typedependent effects of parity on urinary incontinence: the Norwegian EPINCONT study. Obstet Gynecol 2001; 98(6): 1004-10.

21. Subak LL, Richter HE, Hunskaar S. Obesity and urinary incontinence: epidemiology and clinical research update. J Urol 2009; 182: S2-S7.

22. McGrother CW, Donaldson MMK, Hayward T, et al. Urinary storage symptoms and comorbidities: a prospective population cohort study in middle-aged and older women. Age and Ageing 2006; 35: 16-24.

23. Dallosso HM, McGrother CW, Matthews RJ, et al. The association of diet and other lifestyle factors with overactive bladder and stress incontinence: a longitudinal study in women. BJU Int 2003; 92: 69-77. 